\title{
Long-term changes in the plant ecology of an African savanna landscape and the implications for ecosystem theory and conservation management
}

\author{
David Western, Victor N. Mose ${ }^{*}$, David Maitumo and Caroline Mburu
}

\begin{abstract}
Background: Studies of the African savannas have used national parks to test ecological theories of natural ecosystems, including equilibrium, non-equilibrium, complex adaptive systems, and the role of top-down and bottom-up physical and biotic forces. Most such studies have excluded the impact of pastoralists in shaping grassland ecosystems and, over the last half century, the growing human impact on the world's rangelands. The mounting human impact calls for selecting indicators and integrated monitoring methods able to track ecosystem changes and the role of natural and human agencies. Our study draws on five decades of monitoring the Amboseli landscape in southern Kenya to document the declining role of natural agencies in shaping plant ecology with rising human impact.
\end{abstract}

Results: We show that plant diversity and productivity have declined, biomass turnover has increased in response to a downsizing of mean plant size, and that ecological resilience has declined with the rising probability of extreme shortfalls in pasture production. The signature of rainfall and physical agencies in driving ecosystem properties has decreased sharply with growing human impact.

We compare the Amboseli findings to the long-term studies of Kruger and Serengeti national parks to show that the human influence, whether by design or default, is increasingly shaping the ecology of savanna ecosystems. We look at the findings in the larger perspective of human impact on African grasslands and the world rangelands, in general, and discuss the implications for ecosystem theory and conservation policy and management.

Conclusions: The Amboseli study shows the value of using long-term integrated ecological monitoring to track the spatial and temporal changes in the species composition, structure, and function of rangeland ecosystems and the role of natural and human agencies in the process of change. The study echoes the widespread changes underway across African savannas and world's rangelands, concluding that some level of ecosystem management is needed to prevent land degradation and the erosion of ecological function, services, and resilience. Despite the weak application of ecological theory to conservation management, a plant trait-based approach is shown to be useful in explaining the macroecological changes underway.

Keywords: Savannas, Plants, Human dominance, Macroecology, Conservation

\footnotetext{
*Correspondence: vnmose@gmail.com

African Conservation Centre, P. O. Box 15289-00509, Nairobi, Kenya
}

\section{Springer Open}

(- The Author(s). 2021 Open Access This article is licensed under a Creative Commons Attribution 4.0 International License, which permits use, sharing, adaptation, distribution and reproduction in any medium or format, as long as you give appropriate credit to the original author(s) and the source, provide a link to the Creative Commons licence, and indicate if changes were made. The images or other third party material in this article are included in the article's Creative Commons licence, unless indicated otherwise in a credit line to the material. If material is not included in the article's Creative Commons licence and your intended use is not permitted by statutory regulation or exceeds the permitted use, you will need to obtain permission directly from the copyright holder. To view a copy of this licence, visit http://creativecommons.org/licenses/by/4.0/. 


\section{Background}

Research over the last five decades has shown the plant structure and composition of African savanna communities to be shaped by physical and biotic factors. Protected areas have been widely used as inferential models to pose and test ecological theories of natural ecosystem (Sinclair and Norton-Griffiths 1979). The theoretical models include equilibrium, non-equilibrium, multistate equilibria, and complex adaptive systems (Caughley 1976; Walker and Noy-Meir 1982; Dublin et al. 1990; Gillson 2004), and the role of top-down and bottom-up driving forces and their interactions (Power 1992).

Despite hunter-gatherers shaping the African savannas since the late Pleistocene (Redman 1999; Archibald et al. 2012) and the growing impact of farming and pastoralism through the Neolithic (Nentwig 2007; Wright 2017), human activity has been largely ignored in ecological studies. Pastoralism spread into eastern Africa at the end of the African Humid Period 4000 BP (Marshall and Hildebrand 2002), and livestock has since become numerically dominant to wild herbivores across African woodland and grassland ecosystems (Bourn 1978; Fritz and Duncan 1994). As a result, wildlife populations have declined steeply over the last half century due to rapid human population and economic growth (Craigie et al. 2010; Ogutu et al. 2016).

Whereas early studies of savannas ecosystems used national parks as baselines for inferring the ecology of naturally functioning systems (Sinclair, 1998), recent studies have shown the indirect impact of human activities to modify vegetation composition in even the largest parks (du Toit et al. 2003; Sinclair et al. 2015). Collectively, the segregation of formerly interlinked ecologies of wildlife and pastoralism can cause ecological knock-on effects independent of park size (Western and Gichohi 1993).

The ubiquity of the human imprint calls for monitoring ecosystems with sufficient resolution to detect the ecological changes and the role of natural and human agencies, and assess the implications for ecological theory and ecosystem conservation. The adequacy of a monitoring program to detect and decipher ecological changes hinges on the selection of indicators and protocols able to track the complexity and interconnectedness of ecosystem processes (Dale and Beyeler 2001). Other considerations include the choice of sampling procedures, consistency of monitoring, and its longterm sustainability (Hinds 1984). Poor spatial coverage and infrequent sampling, in particular, complicate the task of untangling oscillations from directional trends and, consequently, make it hard to distinguish human-induced from natural fluctuations, test ecological theories, and offer guidelines for conservation policy and management.
Here, we draw on a long-term monitoring study of a savanna landscape in southern Kenya to track the changes in vegetation and the declining responsiveness to natural processes. Conducted by the Amboseli Conservation Program (ACP), the study monitored human activity, including farming, livestock numbers, human settlement, and poaching, as well as wildlife populations, habitat changes, and plant composition and ecological properties (Western and Nightingale 2004; Western and Behrensmeyer 2009; Mose et al. 2012).

Our main aim is to document the changing structure and ecological characteristics of a savanna ecosystem over the last half century. We use habitat type, tree, shrub, herb and grass biomass, and species composition to measure changes in plant structure, composition, production, size frequency, richness, diversity, and resilience to measure the changes in the Amboseli ecosystem. We show that the changes are commensurate with humaninduced changes across the African savannas and rangelands of the world. The study underscores the importance and feasibility of long-term monitoring programs in tracking natural and human-induced changes, and highlights the use of a trait-based ecological approach in deciphering and explaining the interlocking changes.

\section{Study area}

The greater Amboseli ecosystem covers the $8500 \mathrm{~km}^{2}$ migratory range of the wild herbivore and pastoral livestock populations which move seasonally between wet and dry season pastures and portions of adjacent ecosystems. The ecosystem lies between latitudes $2^{\circ}-3^{\circ} \mathrm{S}$ and longitudes $36.5^{\circ}-38^{\circ} \mathrm{E}$ ranging in elevation from 1200 to $1500 \mathrm{~m}$ located north of Mt. Kilimanjaro along the Kenya-Tanzania border (Western et al., 2009). Both wild herbivores and Maasai herds spread widely during the rains and aggregate in the dry season around the permanent swamps of the Amboseli basin (Western 1973).

The ecosystem has been described in detail in several publications (Western 1973; Western and Dunne 1979; Western and Nightingale 2004; Western and Behrensmeyer 2009; Moss et al. 2011; Mose et al. 2012). Maximum temperatures vary between 26 and $44{ }^{\circ} \mathrm{C}$ and minimum temperatures between 6 and $14{ }^{\circ} \mathrm{C}$ (Western, 1973, Altmann et al., 2002). Rainfall averages $350 \mathrm{~mm}$ annually with rains during October to December and March to May. The dominant vegetation is bushed grassland classified as ecological Zone V (Pratt et al. 1966). Aquifers from the northern forests of Kilimanjaro filter into the Amboseli basin and sustain a series of permanent swamps and hydrophilic woodlands dominated by Acacia xanthophloea.

The Amboseli ecosystem has been occupied by Maasai pastoralists for over half a millennium. The Maasai traditionally subsisted largely on the milk and meat of cattle, 
supplemented by sheep and goats (Jacobs 1965; Homewood 2008). Starting in the 1960s, the higher rainfall areas on the slopes of Kilimanjaro were partitioned into private farms which, over the following decades, spread downslope to the permanent swamps and rivers of Namelog and Kimana. The Ilkisongo section of the Maasai continued to track the wildlife migrations seasonally across the ecosystem until 1977 when livestock was excluded from the $388 \mathrm{~km}^{2}$ Amboseli National Park, which aimed at protecting wildlife and promoting tourism. Starting in the 1970s, communally owned lands in the Amboseli ecosystem were divided into seven group ranches held under joint title deed by the customary pastoral occupants (Kimani and Pickard 1998; Ntiati 2002; BurnSilver and Mwangi 2007). Seasonal herding practices nonetheless continued until the late 1980 s when pastoral families began setting up permanent settlements to gain access to social services (Western and Nightingale 2004; Muchiru et al. 2008; Western et al. 2009).

\section{Methods}

The habitat composition of the $700 \mathrm{~km}^{2}$ Amboseli basin was described and mapped in 1967, transposed onto 1950 aerial photos and updated every 5 years through to 2002 (Western 2007). Twenty-five vegetation zones were initially described using Poore's (1962) successive approximation technique. Several zones too small to warrant distinction were later amalgamated into larger zones, and three new zones were added as the vegetation composition changed over the ensuing decades. The vegetation zones were lumped into eight major habitats: grasslands, dense woodlands, open woodlands, dense bush, open bush, swamp edge, permanent swamp, and Suaeda scrub for ease of interpretation and analysis (Western, 2007). The major habitats are shown in Fig. 1.

The structure and composition of Amboseli habitats was initially sampled quantitatively in 1977 using 101 circular plots $10 \mathrm{~m}$ in radius, giving an area of $314 \mathrm{~m}^{2}$ (Fig. 1). The plots were randomly distributed across the $700 \mathrm{~km}^{2}$ dry season range of the wild and domestic herbivores. Vegetation cover was measured using the point intercept method (Jonasson 1988). For each frame, ten pins were dropped through a slanting pin frame angle of $67^{\circ}$, and each plant hit recorded. Plant cover was estimated as a percentage of total hits over the total number of pins (Western et al. 2015). Grass height was recorded in centimeters. Percentage grazing pressure was estimated from the proportion of grazed and non-grazed hits. The biomass for each species was derived from the equation $\log _{10} D=\log _{10}(H C)-0.38$ (Western and Lindsay 1984), where $D$ is plant dry mass, $H$ is the mean plant height in $\mathrm{cm}$, and $C$ is the percentage ground cover.

Bush and tree cover was sampled using the exclusion quadrant method (Cottam and Curtis 1956). Twenty plots were selected from the randomized set for continuous monthly monitoring of herb layer biomass and seasonal species composition (Western et al. 2015). To detect trends in plant characteristics, we used a modified non-parametric Mann-Kendall trend test $(\tau)$ analysis (Hamed and Rao 1998). The advantage of the modified Mann-Kendall analysis is its ability to incorporate

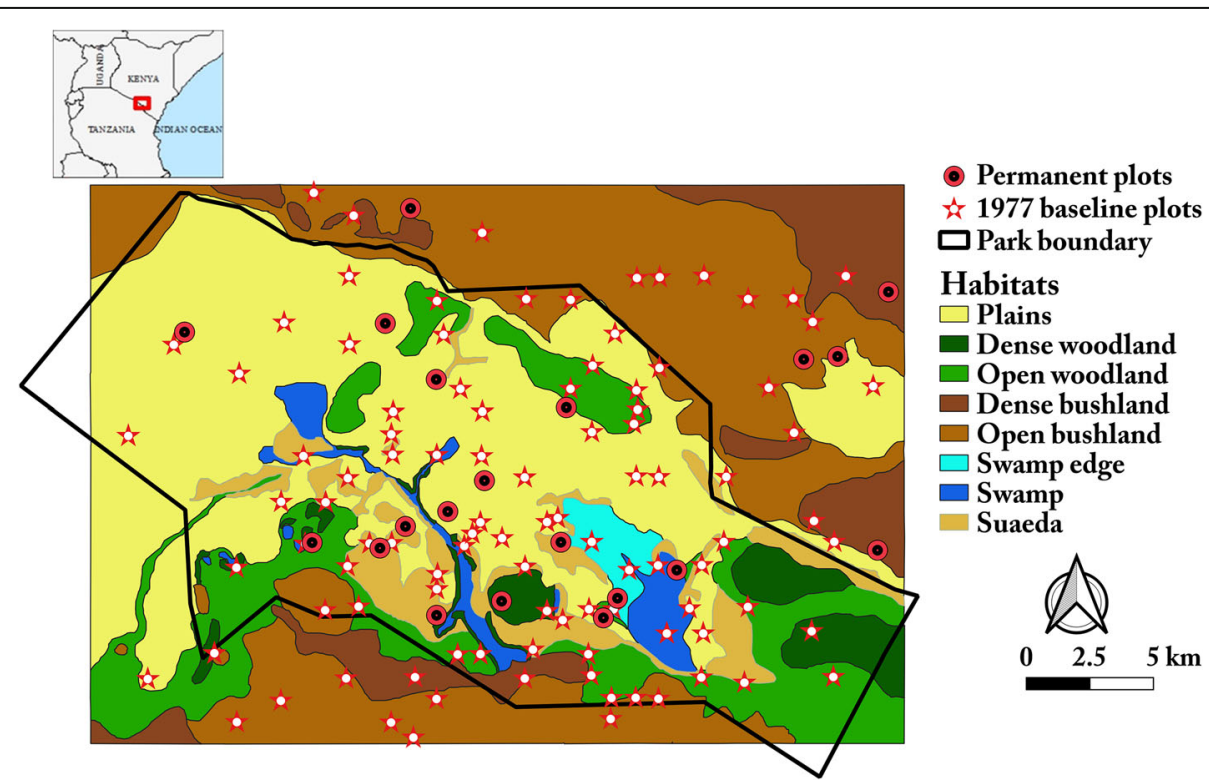

Fig. 1 Major habitats amalgamated into eight habitats from 29 vegetation zones defined in the 1967 baseline and subsequent surveys. The distribution of the 101 randomized plots in the 1977 species composition survey and the 20 subplots monitored every 4 to 6 weeks are shown. The permanent vegetation plots selected from the randomized set and measured monthly are distinguished by circles 
possible autocorrelation in time series data, recognizing that vegetation biomass levels depend significantly on the previous month's biomass stock.

The changes in species composition in each habitat were based on relative abundance using a detrended correspondence analysis (DCA) and ordination technique of Hill and Gauch (1980). Changepoint analysis was used to identify significant fluctuations in plant biomass, diversity, dominance, richness, size frequency, and production. We used the Behavioral Change Point Analysis (BCPA) in R (R Core Team 2020) to detect the likelihood of significant changes in long-term datasets (Gurarie 2014).

The macroecological changes in the vegetation structure and composition of the Amboseli plant community were quantified using measures of plant size frequency, turnover rate, species richness, diversity, dominance, and productivity. The size frequency of woody plants was calculated using the following formula:

$$
\bar{w}_{t}=\frac{1}{N_{t}} \sum_{i} n_{i t} \bar{x}_{i}
$$

At time $t, \bar{w}_{t}$ is the size frequency for all plants (mean biomass weight of all species combined), $N_{t}$ is the total number of species sampled, $n_{i t}$ is the number of species $i$ observed during the survey, and $\bar{x}_{i}$ is taken as the mean weight of species $i$. Changes in plant production were calculated for tree, shrub, and herb biomass for individual species, based on the average weights and specific gravity for each species in Amboseli. The total production for all species combined was calculated using the equation

$$
P_{t}=\sum_{i} n_{i t} \bar{x}_{i}^{0.763}
$$

At time $t, P_{t}$ is estimated as the production for all plants, $n_{i t}$ is the number of species $i$ observed during the survey, and $\bar{x}_{i}$ is the mean weight of species $i$.

\section{Results}

\section{Habitat changes}

Habitat changes over the five decades from 1950 to 1997 have been detailed in a previous publication (Western 2007). Here, we have extended the analysis to 2017. Of the 25 vegetation zones mapped in 1967 (Western 1973) and tracked since 1950 from aerial photo coverage, dense and open Acacia xanthophloea habitat was replaced by Suaeda monoica shrubland. Dense Acacia tortilis woodlands and Acacia mellifera bushlands were replaced by open scrub and herbaceous habitats. The mixed Acacia xanthophloea and Phoenix reclinata zone lost most of its Acacia trees before being replaced by open grasslands. Classifying the vegetation zones into woodland (open and dense woodland), bushland (open and dense bushland), scrubland (Suaeda), grassland (plains), swamp, and swamp-edge habitats (Fig. 2) shows woodlands have shrunk from 25\% cover in 1950 to $5 \%$ in 2017, and grassland has expanded from 28 to $40 \%$ cover. Swamp and swamp-edge habitats, which expanded with the loss of woodlands, have shown minor changes since the 1990s, corresponding to fluctuations in water discharge from Kilimanjaro.

The reduction in habitat diversity based on the 25 vegetation zones mapped in 1967 is striking. The highly significant decline $\left(r=-0.91, r^{2}=0.82, P<0.0001\right)$ measured by the Shannon-Wiener's diversity (Peet 1974) index is shown in Fig. 3.

\section{Plant biomass}

Total biomass declined steeply from over $600 \mathrm{gm}^{-2}$ in the 1970 s to $200 \mathrm{gm}^{-2}$ in 2017 ( $\tau=-0.66, P<0.001$ ). The decline in vegetation biomass was significant for all habitats except the plains (Table S1). The largest contributors to the biomass decline were the woodland (30\%), swamp (20\%), and swamp edge habitats (14\%).

\section{Biomass composition}

Figure 4 illustrates the changes in tree, shrub, herb, and grass biomass for all habitats combined. A modified Mann-Kendall trend test (Hamed and Rao 1998) shows a significant decline in tree $(\tau=-0.409, P<0.001)$, shrub $(\tau=-0.609, P<0.001)$, and grass biomass $(\tau=-$ $0.355, P=0.007)$, but not in herb biomass $(\tau=0.118, P=$ 0.378 ). Herb biomass did, however, decline significantly after 1994 ( $\tau=-0.412, P=0.018)$. The largest contributor to the overall decline was the loss of grass and tree biomass. Tree and shrub biomass declined significantly

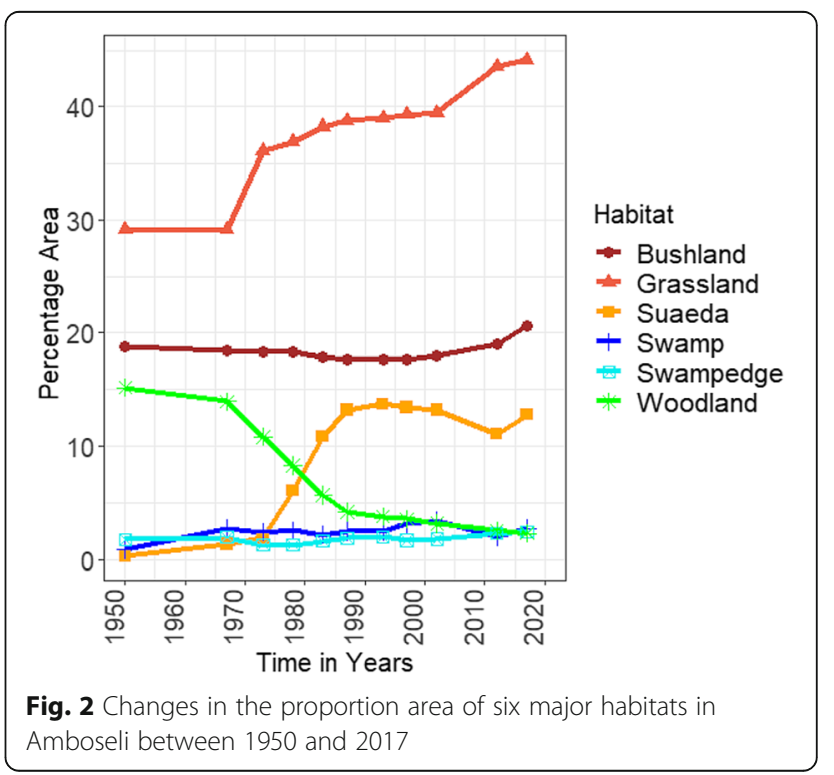




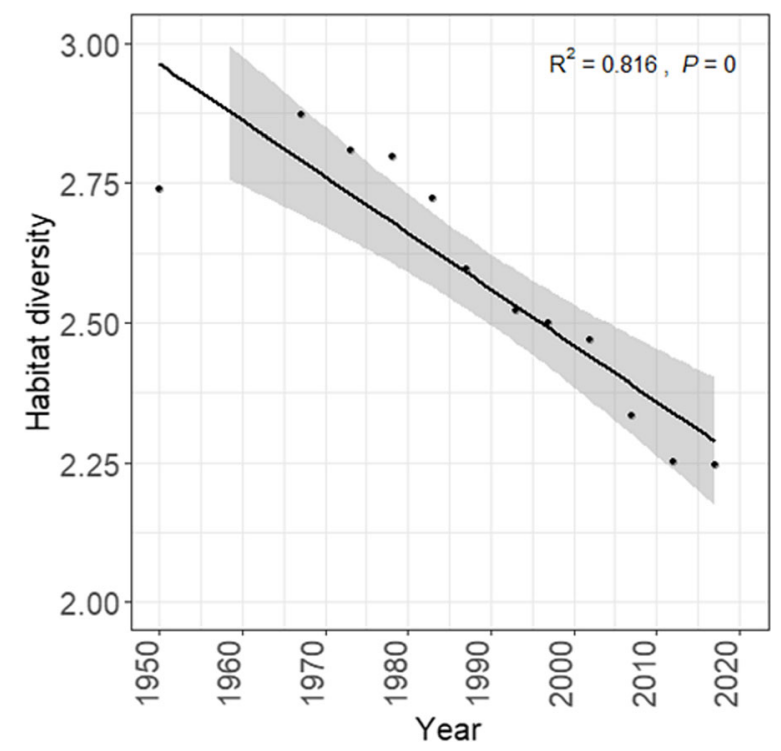

Fig. 3 Shannon-Wiener's index of diversity based on the 25 vegetation zones originally mapped in Amboseli in 1967 and transposed onto 1950 aerial photos

in all habitats; grass biomass declined in woodland, swamp, and swamp-edge habitats; and herbs only declined in woodland habitats.

The decline in tree and shrub species in all habitats resulted in a convergence in biomass heterogeneity between habitats. A dissimilarity index based on biomass differences between the twenty permanent plots distributed across all habitats decreased over time $(\tau=-0.326$, $P=0.02$ ). The convergence was largely due to the reduction of tree, shrub, and sedges in the high biomass

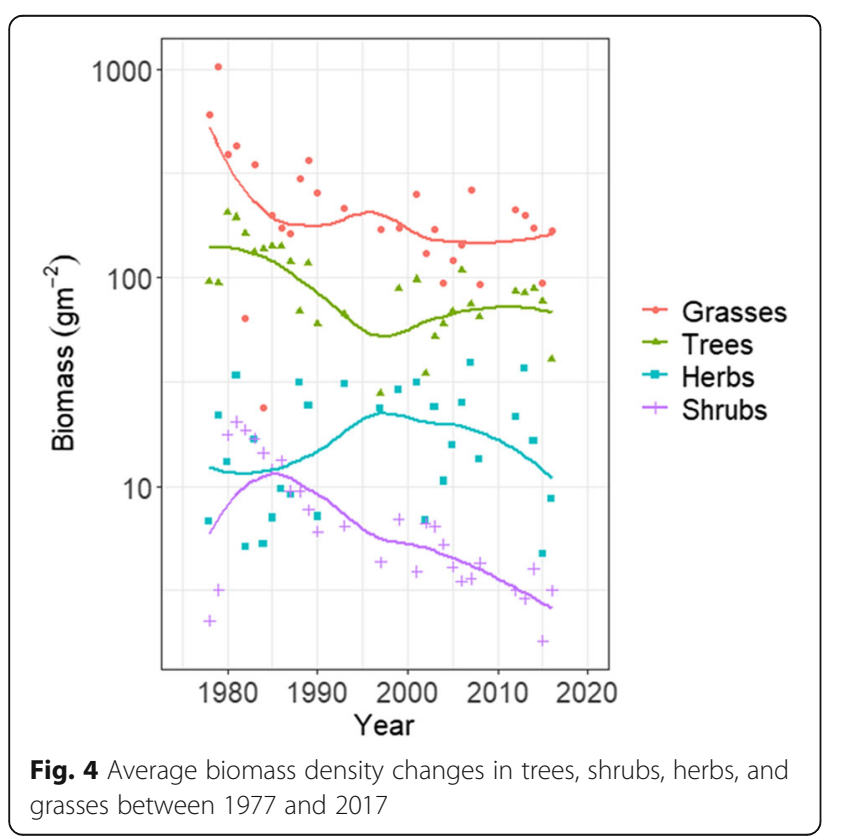

woodland, swamp-edge, and swamp habitats in favor of low biomass grasslands, Suaeda, and bushland habitats.

\section{Species similarity and turnover}

Species richness in the 20 permanent plots declined between 1977 and $2017(\tau=-0.326, P=0.02)$ based on species comprising $4 \%$ or more of the 101 randomly selected plots in the 1977. The list of 73 plant species included in the analysis is given in Table S2.

A Sorensen's similarity index (Sorensen 1948) of species composition showed no significant change in the bushland ( $\mathbf{\tau}=0.027, \mathbf{P}=0.87)$ and plain habitats $(\mathbf{\tau}=-$ $0.071, \mathbf{P}=0.62)$, but a significant increase in the woodlands $(\mathbf{\tau}=0.32, \mathbf{P}=0.027)$ and swamp-edge habitats $(\mathbf{\tau}=$ $0.30, \mathbf{P}=0.041)$.

\section{Changes in species composition}

The changes in species composition in each habitat are shown in Fig. 5. The analysis includes the most abundant species which have cumulatively contributed 95\% of the total plant biomass. The clustering was pronounced in the 1970s, with the woodland and swamp habitats showing close similarity and the plains, Suaeda, and bushland habitats a clearer delineation along axis 1 (DCA1). Suaeda and plain habitats were closely clustered on axis 2 (DCA2) and distinct from the bushlands. By the 2010s, the distinctions between habitats declined sharply, pointing to a narrowing species composition.

\section{Macroecological changes}

The temporal changes in total production of trees, shrubs, and herbs combined are given in Fig. 7. Production declined sharply from $1977(\tau=-0.758, \quad P<0.001)$ to the change point in 1997 , followed by a small recovery. The decline in production corresponds to changes in size frequency $(\tau=-0.354, P=0.012)$, pointing to the loss of trees and large shrubs as the main cause of decline (Fig. 6). Given the functional relationship between species size $(M)$ and growth rate $(G)$ in $G \alpha M^{0.75}$ (Niklas and Enquist 2001), it follows that annual turnover rate in plant biomass averaged for all habitats is directly correlated with changes in production shown in Fig. 7.

Changes in herb layer biomass aggregated for the 20 permanent plots are shown in Fig. 8. The graph expands the 1982 to 2010 coverage cited in Western et al. (2015) to 2018. Herb layer biomass declined significantly over the last five decades $(\tau=-0.223, P<0.001)$. The change point at 1998 closely matches the change point in size frequency and production of woody vegetation (Figs. 6 and 7), again showing an upturn with the exceptionally heavy El Niño rains of 1998. 

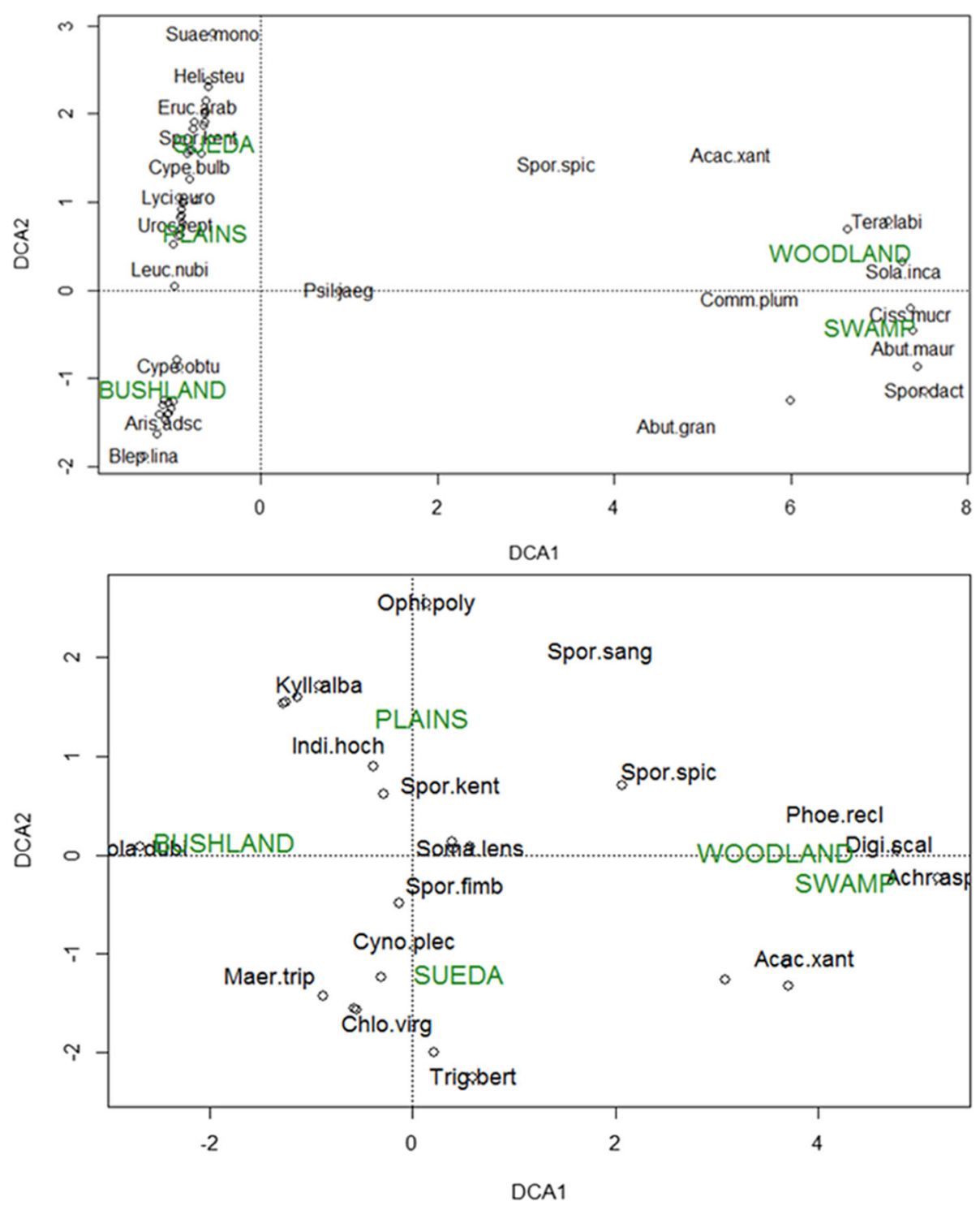

Fig. 5 Detrended correspondence analysis ordination shows the increasing similarity in species composition among habitats between the 1970s (top) and 2010s (below). The names shown in the figures are the first four letters of the genus and species names. The complete species list is provided in Table $\mathrm{S} 2$

Changes in the resilience of vegetation (Walker and Noy-Meir 1982) can be gauged by a reduced production response to rainfall and in seasonal production normalized for rainfall. Western et al. (2015) used the declining response of pasture production to rainfall in Amboseli to show a loss of resilience due to intensified herbivory from 1982 to 2010. Figure 9 shows the data extended to 2018. The diminished response of production to rainfall is highly significant $(\tau=-0.256, P<0.001)$, giving a direct measure of the decline in the resilience of the herb layer community.

We found a similar loss of woody plant resilience using the same method to measure the decline in production (Fig. 7) per unit of rainfall $(\tau=-0.169$,
$P=0.012)$. We also found a decrease in resilience measured by an increase in plant seasonality. We used the likelihood ratio test to determine the probability of increased forage and rainfall seasonality by comparing a null regression model with a model including time in years for rainfall and forage seasonality. The model yielded a significant fit for forage shortfalls $\left(X_{(1)}^{2}=24.04, P<0.0001\right)$, signaling a rising likelihood of extreme deficits, despite showing no significant rise in the probability of rainfall deficits ( $\left.X_{(1)}^{2}=1.98, P=0.1592\right)$.

Changes in species diversity (Simpson 1949; Peet 1974), richness, and dominance (McNaughton and Wolf 


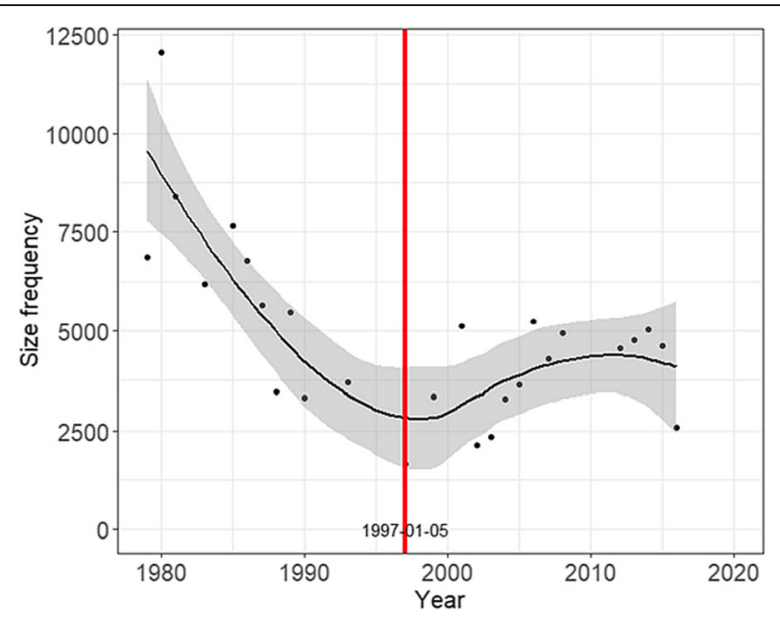

Fig. 6 Changes in size frequency of woody plants showing the change point in 1997

1970) used as measures of macroecological change in all plots combined are shown in Fig. 10. Diversity $(\boldsymbol{\tau}=-$ $0.573, \quad \boldsymbol{P}<0.0001)$ and dominance $(\boldsymbol{\tau}=0.317, \quad \boldsymbol{P}=0.025)$ declined steadily over the study period but most strongly after the change point in the late 1990s. Species richness over the study period showed no significant change ( $\boldsymbol{\tau}=$ $-0.197, \boldsymbol{P}=0.17$ ) but did show a significant decline after the 1990 change point $(\boldsymbol{\tau}=-0.402, \boldsymbol{P}=0.044)$. The change point in each case is similar, showing a decline in species richness and diversity and an increase in dominance to have accelerated after the 1990s. The decline corresponds to the replacement of the woodlands by

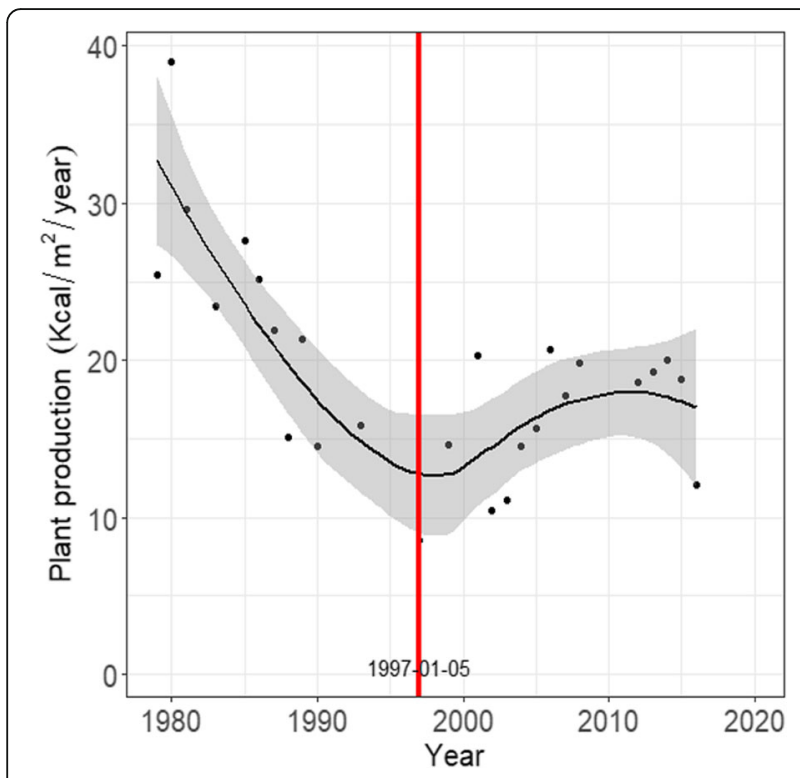

Fig. 7 Changes in production aggregated for trees, shrubs, and herbs combined for 20 permanent monitoring plots and all major Amboseli habitats. The red line shows the most significant changepoint. Annual growth rate is used as a proxy for production
Suaeda (Fig. 2) and the decline in size frequency with the loss of large trees (Fig. 6).

\section{Discussion}

The Amboseli monitoring program shows the value of long-term ecological research sites (Franklin et al. 1990) in tracking a wide range of plant properties in an ecosystem in response to natural and human agencies. The study also points to the need to view protected areas within a larger landscape context in order to capture the external causes of vegetation changes. The results also illustrate the variety of information which can be gathered for documenting and exploring the interconnected ecosystem changes.

In the case of Amboseli, the results track the declines in habitats, tree, shrub, herb and grass biomass, species diversity, and mean plant size since the 1970s. Species dominance has risen as species diversity has fallen, and annual biomass turnover has grown inversely with diminishing plant size. Plant productivity has declined, seasonality has increased, and the probability of extreme shortfalls has risen. Taken together, the results show that the production, diversity, ecological function, and resilience of the plant community have all declined sharply over the last five decades.

Prior to the 1990s change point, a simple regression model shows rainfall to significantly predict total plant biomass $\left(r^{2}=0.45, P=0.012\right)$, grass biomass $\left(r^{2}=0.56\right.$, $P=0.003)$, tree biomass $\left(r^{2}=0.32, P=0.046\right)$, and shrub biomass $\left(r^{2}=0.43, P=0.014\right)$ and marginally herb biomass $\left(r^{2}=0.43, P=0.082\right)$. After 1990 , rainfall falls to insignificance in predicting total biomass $\left(r^{2}=0.21, P=\right.$ $0.071)$, tree biomass $\left(r^{2}=0.03, P=0.514\right)$, shrub biomass $\left(r^{2}=0.07, P=0.336\right)$, and herb biomass $\left(r^{2}=0.05, P=\right.$ $0.386)$ and becomes a weak predictor of grass biomass $\left(r^{2}=0.25, P=0.049\right)$.

The declining significance of rainfall corresponds to an increase in browsing and grazing pressure in recent decades. So, for example, the loss of Acacia woodlands and woody vegetation (Western and Van Praet 1973; Western and Maitumo 2004) was shown in a 20-year elephant exclusion experiment (Western 2007). The heavy browsing resulted from the recovery of elephant populations throughout East and Central Africa after the decline of the 19th century ivory trade (Parker and Amin 1983; Cumming et al. 1997; Håkansson 2004). In Amboseli, the growth in elephant numbers was coupled with a concentration of herds into the safety of Amboseli National Park in the 1970s (Western and Lindsay 1984; Moss 2012) during a surge in poaching across Africa (Douglas-Hamilton 1987). A meta-analysis of many studies shows that high densities of elephants reduce woody vegetation in dry savannas (Guldemond and Van Aarde 2008). 


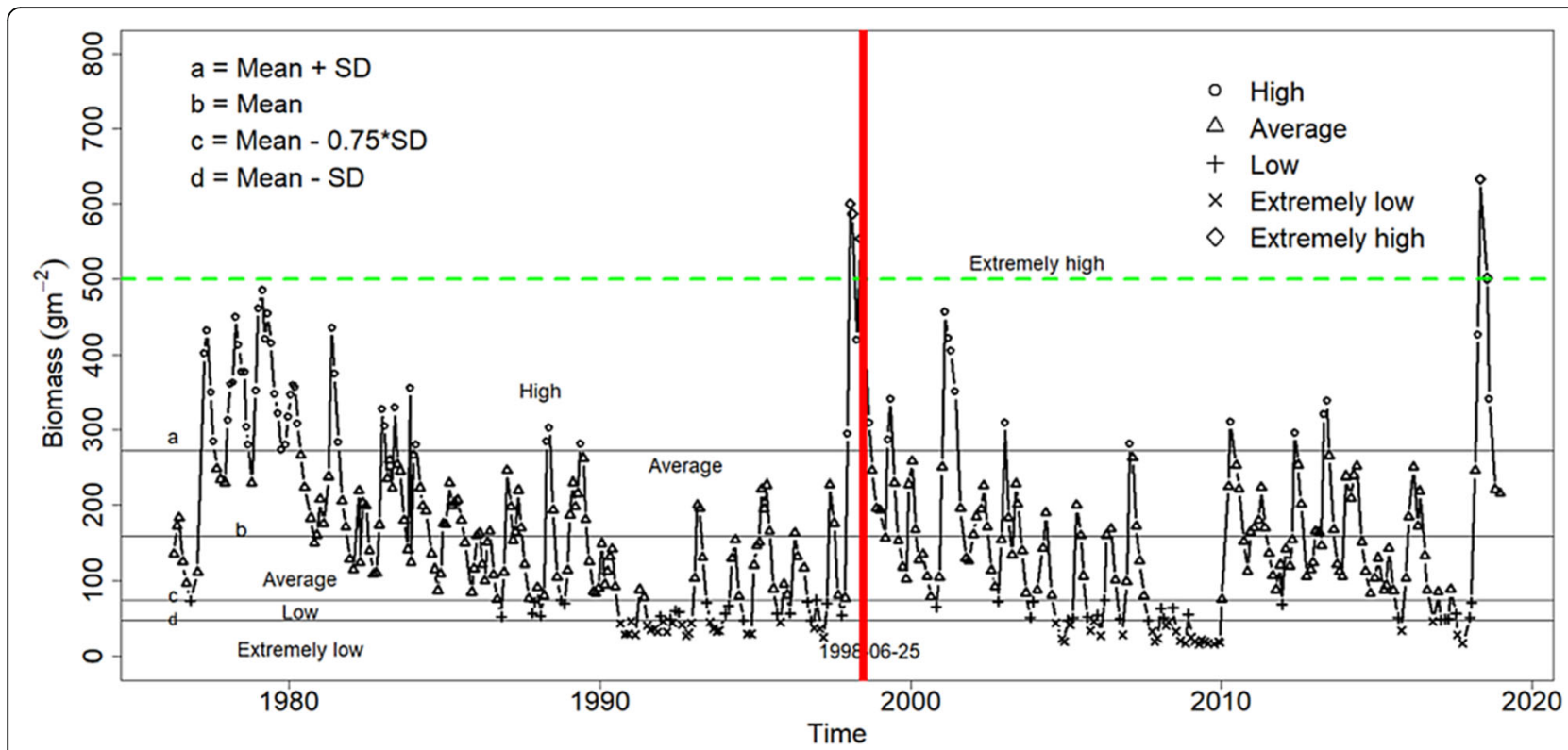

Fig. 8 Pasture biomass averaged for 20 permanent plots measured across the major habitats of Amboseli

The $30 \%$ decline in herbaceous productivity has been attributed to a three-fold increase in grazing pressure due to intensified pastoralism, land use changes, sedentarization, and reduced livestock mobility (Worden et al. 2003; Groom and Western 2013; Western et al. 2015; Okello et al. 2016), coupled with the compression of wildlife into the late season pastures (Sarkar 2006; Western et al. 2015). The impact of intensified herbivory was anticipated by earlier studies in the Amboseli area. Cassady (1973), for example, showed that repeated grazing through the year reduced plant production by 22 to $60 \%$ relative to controls, whereas heavy defoliation once each dry season sustained production. Georgiadis et al. (1989) further demonstrated in potted plant experiments which manipulated water, nutrient, and defoliation treatments

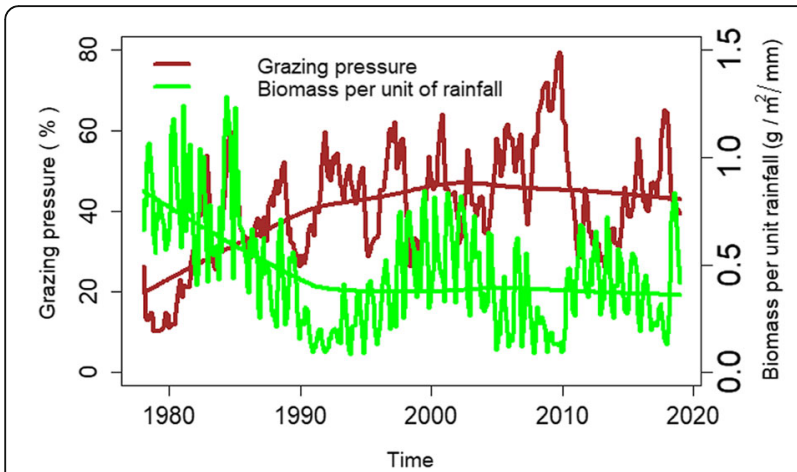

Fig. 9 Decline in the resilience of the plant community measured by the diminished production per unit of rainfall due to intensified grazing pressure. that frequent repeated offtake deletes resilience far more than short-intensive defoliation. Studies by Dunne et al. (2011) experimentally manipulating trampling and grazing showed both factors to depress pasture production per unit of rainfall. The results match similar findings in South America where Toft et al. (1987) showed trampling coupled with heavy grazing reduced plant biomass

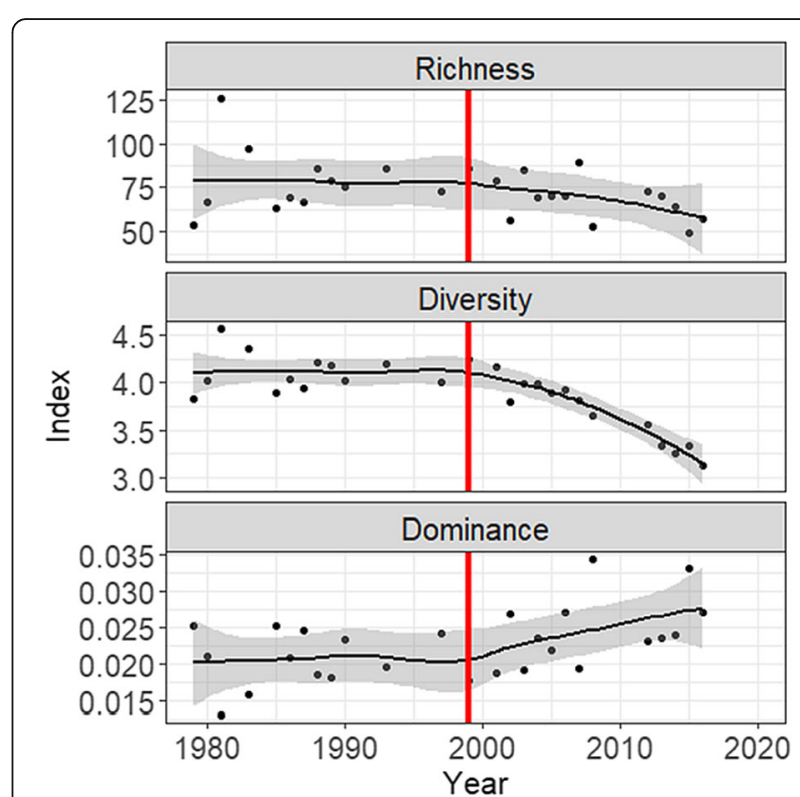

Fig. 10 Changes in species richness, diversity, and dominance showing the significant change points (red lines) cluster around the change point in species size frequency (Fig. 6) 
and caused a convergence in stand floristics across plant communities.

The reduction in plant biomass and productivity in Amboseli applies widely across African grassland ecosystems. Le Houerou (1989), for example, found cultivation and heavy grazing to have reduced grassland and woody vegetation across 3 million $\mathrm{km}^{2}$ of northern Africa since World War II. Dodd (1994) documented similar widespread rangeland degradation in Sub-Saharan Africa. Angerer et al. (2016) have shown similar human-induced changes across the rangelands which cover $40 \%$ of the earth's terrestrial surface. Although the proximate causes of degradation have commonly been attributed to intensified herbivory in each case, the ultimate causes are often complex, including human and livestock population growth, land subdivision and expropriation, social dislocation, a breakdown in governance institutions, and climate change (Palmer and Bennett 2013; Boles et al. 2019)

Most research on African savanna ecosystems in recent decades has focused on changes in large mammals. Widespread declines in wildlife populations have been documented inside as well as outside protected areas across east and southern Africa (Caro and Scholte 2007; Craigie et al. 2010; Ogutu et al. 2016). The causes include loss of range, land transformation, habitat fragmentation, population growth, livestock impact, poaching, lack of local engagement, human-wildlife conflict, insufficient conservation funding, and climate change (Craigie et al. 2010; Ogutu et al. 2016).

In contrast to the large mammal studies of the African savannas, few studies apart from Amboseli have systematically monitored changes in plant communities and their causes and their applications to ecosystem management. The two exceptions include Africa's largest protected areas, the 22,000 $\mathrm{km}^{2}$ Kruger National Park in South Africa, and the $25,000 \mathrm{~km}^{2}$ Serengeti-Mara complex in East Africa. Both parks cover a large and diverse landscape and include almost all the plant and animals that occurred in historical times. The studies underscore the importance of large open landscapes in sustaining natural ecological process, yet also highlight the weakening influence of natural agencies and rising impact of human activity in determining the ecology of animal and plant communities.

In Kruger National Park, which was established in 1926, the vegetation was, until the 1990s, actively managed to prevent the destruction of woodlands by a rising elephant population fenced within the park. Water points, fire, elephant numbers, populations of other large herbivores, and diseases were controlled within defined limits to maintain the park in a relative constant state (Mabunda et al. 2003). Recognizing over-management had created vegetation homogeneity, park policy changed in the 1990s to restore heterogeneity by allowing natural processes to prevail, intervening only to avoid extreme disruptions (du Toit et al. 2003). So, for example, the fence bordering Mozambique was removed to allow greater freedom of elephant movement and reduce the compression effects on vegetation. Further, the long-term studies have shown that a hierarchy of factors and non-linear processes govern ecosystem heterogeneity and shaped the new management policies which recognize Kruger as a complex adaptive system continually responding to new influences (Mills et al. 2003). In short, both management and policy have been guided by a close link between scientific research and conservation goals.

Serengeti, established in 1952, brought together disparate threads of research in the 1960s to describe the processes and patterns governing the Serengeti ecosystem and provide information for management (Sinclair 1973). The research program found tree cover giving way to grasslands due to the recovery of migratory wildebeest populations after the rinderpest epidemic of the late 1900s, and to increased fire, elephant ingress, and changes in rainfall regime (Sinclair 1973). Unlike Kruger, Serengeti management and policy has not been closely guided by research but used to test alternative ecosystem theories, including the stable limit cycles proposed by Caughley (1976) and multiple stable states proposed by Dublin et al. (1990). The studies concluded that neither theory is upheld by data from Serengeti. Rather, the plant community is changing continuously, though with no monotonic trend toward a different compositional state (Woodroffe and Ginsberg 1998).

Later studies that expanded to include surrounding lands dominated by farming and pastoralism, found Serengeti's ecology intertwined with human impact (Sinclair et al. 2015). A recent study of the changes in the spatial distribution of large herbivores and vegetation responses found livestock and farming to have compressed wildlife within the park. The compression caused lower primary production, a loss of favored herbivore grass species, an increase in unpalatable herbs, lower carbon storage, and decreased resistance to rainfall deficits (Veldhuis et al. 2019). The impact of human activity surrounding Serengeti National Park, though muted, mirrors the impact of intensified herbivory in Amboseli, a national park less than $2 \%$ its size.

The long-term research in Amboseli, Kruger, and Serengeti shows the importance of long-term landscapelevel monitoring to the conservation of protected areas. The ecology of parks, even the largest of them, has been shown to be influenced by edge effects (Woodroffe and Ginsberg 1998), insularization (Soule et al. 1979), invasive species (Crowl et al. 2008), and disruptions due to ecological dislocations across park boundaries (Western and Gichohi 1993). 
The long-term studies of African landscapes reflect universal changes underway. On a global scale, for example, Tucker et al. (2018) found that a wide range of species in the Anthropocene show reduced movements and constricted ranges. The findings demonstrate human impact to be so widespread and pervasive as to call for a reclassification of natural biomes as anthromes (Ellis and Ramankutty 2008). The pervasiveness raises the question of whether ecosystem theories have validity or utility in conservation management, whether baseline reference points are useful given millennial changes (Foster and Aber 2004; Briske et al. 2020), and whether species diversity as a measure of ecosystem functionality is useful. Boles et al. (2019), for example, found in all major ecosystems and climatic zones worldwide that, despite no systematic change in species richness, composition had changed extensively. The biodiversity crisis, they concluded, is more of a case of large-scale reorganization than species loss.

Janzen (1998) and Kareiva et al. (2011) assert that human modification is so great and irreversible as to justify "gardening" nature rather than management based on historical templates. Sinclair and Dobson (2015) argue that protected areas can serve as a control to test whether human-dominated ecosystems are sustainable and robust. Based on the continued growth in protected areas worldwide (McNeely and Miller 1983), and the growing conservation efforts in human-dominated landscapes (Berkes 2007), we consider both protected and non-protected areas to play important and complementary roles (Western et al. 2020). We argue that the worldwide biodiversity loss calls for some level of ecosystem management to prevent land degradation and the erosion of ecological function, services, and resilience as documented in detail in Amboseli. Further, the complexity of ecosystems and the multiplicity of human factors call for monitoring human activity as an integral part of research.

\section{Conclusions}

The long-term Amboseli research shows that it is possible to simultaneously monitor the spatial and temporal changes of a wide range of compositional, structural, and functional plant variables, and to detect the changing role of natural and human agencies.

The Amboseli study in encompassing human activity also points to the weaknesses of using parks as referential models of natural ecosystems and the importance of human dimensions in accounting for ecological changes within parks. Further, although ecosystem theories are proving of limited value in conservation policy and management, the results of the long-term monitoring in Amboseli support a growing body of ecologists who consider functional traits to offer a useful framework for drawing ecological generalities and making predictions (Levin 1998). The macroecological synthesis linking organism size, life history traits, and function, already well established in animals (Brown and Maurer 1989; Smith et al. 2014), has also been shown to apply to plants (Díaz et al. 2016; Kunstler et al. 2016), based on universal scaling laws (Enquist et al. 1999; West et al. 1999; Enquist 2002). Levin (1998) concludes that with the likelihood of climate change creating new species and novel assemblages, a trait-based approach may be the only way to predict interactions and outcomes. The Amboseli study bears out the utility of a trait-based approach in explaining the interconnected cascade of changes in plant communities linked to changes in size frequency.

\section{Declarations}

\section{Supplementary Information}

The online version contains supplementary material available at https://doi. org/10.1186/s13717-021-00286-5.

Additional file 1:. Electronic Supplemental Material (ESM)

\section{Abbreviations}

ACP: Amboseli Conservation Program; DCA: Detrended correspondence analysis; BCPA: Behavioral Change Point Analysis

\section{Acknowledgements \\ We wish to thank the Kenyan Government, the wardens and staff of the Amboseli National Park, and members of the Maasai community who have supported DW's research and conservation work in Amboseli Conservation Program since 1967. We also thank the staff of the African Conservation Centre who have given ACP office facilities and support services and the many donors contributing to the project.}

\section{Authors' contributions}

DW has designed, directed, and funded Amboseli Conservation Program (ACP) since its origins in 1967. DM has served as research field assistant to ACP since 1977 and collected most of the permanent plot data used in the analysis. VNM has overseen the computer database, analytical design, statistical analysis, and modeling used in this article; assisted in the analysis by $\mathrm{CM}$; and is an intern and research associate to the project. All authors read and approved the final manuscript.

\section{Authors' information}

DW (Ph.D.) established the Amboseli Conservation Program (ACP) in 1967 and is a former director of the Kenya Wildlife Service. VNM (Ph.D.) is ACP's Biostatistician and co-director. DM (KCE) is ACP's field researcher since 1977. CM (MSC) is a research associate of ACP.

\section{Funding}

The main donors funding ACP over the years include the Wildlife Conservation Society and the Liz Claiborne Art Ortenberg Foundation.

\section{Availability of data and materials}

The plant data used in this paper can be requested directly via www. amboseliconservation.org or from the Database Administrator, Amboseli Conservation Program (acc@acc.or.ke).

Ethics approval and consent to participate Not applicable.

Consent for publication

Not applicable. 


\section{Competing interests}

The authors declare no competing interests.

\section{Received: 26 September 2020 Accepted: 9 February 2021} Published online: 23 February 2021

\section{References}

Altmann J, Alberts SC, Altmann SA, Roy SB (2002) Dramatic change in local climate patterns in the Amboseli basin, Kenya. Afr J Ecol 40:248-251

Angerer JP, Fox WE, Wolfe JE (2016) Land degradation in rangeland ecosystems. In: Shroder JF, Sivanpillai R (eds). Biological and Environmental Hazards, Risks, and Disasters. Elsevier, pp 277-311

Archibald S, Staver AC, Levin SA (2012) Evolution of human-driven fire regimes in Africa. Proc Natl Acad Sci 109:847-852

Berkes F (2007) Community-based conservation in a globalized world. Proc Natl Acad Sci 104:15188-15193

Boles OJC, Shoemaker A, Mustaphi CJC et al (2019) Historical ecologies of pastoralist overgrazing in Kenya: long-term perspectives on cause and effect. Hum Ecol 47:419-434

Bourn D (1978) Cattle, rainfall and tsetse in Africa. J Arid Environ 1:49-61

Briske DD, Coppock DL, Illius AW, Fuhlendorf SD (2020) Strategies for global rangeland stewardship: assessment through the lens of the equilibrium-nonequilibrium debate. J Appl Ecol 57:1056-1067

Brown JH, Maurer BA (1989) Macroecology: the division of food and space among species on continents. Science 243:1145-1150

BurnSilver S, Mwangi E (2007) Beyond group ranch subdivision: collective action for livestock mobility, ecological viability, and livelihoods. A paper presented at the Pastoralism and Poverty Reduction in East Africa: A Policy Research Conference, 27-28th June 2006, Safari Park Hotel, Nairobi

Caro T, Scholte P (2007) When protection falters. Afr J Ecol 45:233-235

Cassady JT (1973) The effect of rainfall, soil moisture and harvesting intensity on grass production on two rangeland sites in Kenya. East African Agric For J 39: 26-36

Caughley G (1976) The elephant problem-an alternative hypothesis. Afr J Ecol 14: 265-283

Cottam G, Curtis JT (1956) The use of distance measures in phytosociological sampling. Ecology 37:451-460

Craigie ID, Baillie JEM, Balmford A et al (2010) Large mammal population declines in Africa's protected areas. Biol Conserv 143:2221-2228

Crowl TA, Crist TO, Parmenter RR et al (2008) The spread of invasive species and infectious disease as drivers of ecosystem change. Front Ecol Environ 6:238246

Cumming DHM, Fenton MB, Rautenbach IL et al (1997) Elephants, woodlands and biodiversity in southern Africa. S Afr J Sci 93:231-236

Dale VH, Beyeler SC (2001) Challenges in the development and use of ecological indicators. Ecol Indic 1:3-10

Díaz S, Kattge J, Cornelissen JHC et al (2016) The global spectrum of plant form and function. Nature 529:167-171

Dodd JL (1994) Desertification and degradation in sub-Saharan Africa. Bioscience 44:28-34

Douglas-Hamilton I (1987) African elephants: population trends and their causes. Oryx 21:11-24

du Toit JT, Rogers KH, Biggs HC (eds) (2003) The Kruger experience: ecology and management of savanna heterogeneity, 2nd edn. Island Press, Washington DC

Dublin HT, Sinclair ARE, McGlade J (1990) Elephants and fire as causes of multiple stable states in the Serengeti-Mara woodlands. J Anim Ecol 59:1147-1164

Dunne T, Western D, Dietrich WE (2011) Effects of cattle trampling on vegetation, infiltration, and erosion in a tropical rangeland. J Arid Environ 75:58-69

Ellis EC, Ramankutty N (2008) Putting people in the map: anthropogenic biomes of the world. Front Ecol Environ 6:439-447

Enquist BJ (2002) Universal scaling in tree and vascular plant allometry: toward a general quantitative theory linking plant form and function from cells to ecosystems. Tree Physiol 22:1045-1064

Enquist BJ, West GB, Charnov EL, Brown JH (1999) Allometric scaling of production and life-history variation in vascular plants. Nature 401:907-911

Foster DR, Aber JD (2004) Forests in time: the environmental consequences of 1,000 years of change in New England. Yale University Press, New Haven

Franklin JF, Bledsoe CS, Callahan JT (1990) Contributions of the long-term ecological research program. Bioscience 40:509-523
Fritz H, Duncan P (1994) On the carrying capacity for large ungulates of African savanna ecosystems. Proc R Soc London Ser B Biol Sci 256:77-82

Georgiadis NJ, Ruess RW, McNaughton SJ, Western D (1989) Ecological conditions that determine when grazing stimulates grass production. Oecologia 81:316-322

Gillson L (2004) Testing non-equilibrium theories in savannas: 1400 years of vegetation change in Tsavo National Park, Kenya. Ecol Complex 1:281-298

Groom RJ, Western D (2013) Impact of land subdivision and sedentarization on wildlife in Kenya's southern rangelands. Rangel Ecol Manag 66:1-9

Guldemond R, Van Aarde R (2008) A meta-analysis of the impact of African elephants on savanna vegetation. J Wildl Manage 72:892-899

Gurarie E (2014) bcpa: behavioral change point analysis of animal movement. R package version 1.1

Håkansson NT (2004) The human ecology of world systems in East Africa: the impact of the ivory trade. Hum Ecol 32:561-591

Hamed KH, Rao AR (1998) A modified Mann-Kendall trend test for autocorrelated data. J Hydrol 204:182-196

Hill MO, Gauch HG (1980) Detrended correspondence analysis: an improved ordination technique. In: Classification and ordination. Springer, pp 47-58

Hinds WT (1984) Towards monitoring of long-term trends in terrestrial ecosystems. Environ Conserv 11:11-18

Homewood K (2008) Ecology of African pastoralist societies. James Currey

Jacobs AH (1965) The traditional political organization of the pastoral Maasai. D. Phil, thesis, Oxford University, Oxford

Janzen D (1998) Gardenification of wildland nature and the human footprint Science 279:1312-1313

Jonasson S (1988) Evaluation of the point intercept method for the estimation of plant biomass. Oikos 52:101-106

Kareiva P, Lalasz R, Marvier M (2011) Conservation in the Anthropocene: beyond solitude and fragility. Breakthr J 2:29-37

Kimani K, Pickard J (1998) Recent trends and implications of group ranch subdivision and fragmentation in Kajiado District, Kenya. Geogr J 164:202-213

Kunstler G, Falster D, Coomes DA et al (2016) Plant functional traits have globally consistent effects on competition. Nature 529:204-207

Le Houerou HN (1989) An assessment of the economic feasibility of fodder shrubs plantation (with particular reference to Africa). In: The Biology and Utilization of Shrubs. Academic Press, pp 603-630

Levin SA (1998) Ecosystems and the biosphere as complex adaptive systems. Ecosystems 1:431-436

Mabunda D, Pienaar DJ, Verhoef J (2003) The Kruger National Park: a century of management and research. In: du Toit JT, Rogers KH, Biggs HC (eds) The Kruger experience: ecology and management of savanna heterogeneity. Island Press, Washington DC, pp 3-21

Marshall F, Hildebrand E (2002) Cattle before crops: the beginnings of food production in Africa. J World Prehistory 16:99-143

McNaughton SJ, Wolf LL (1970) Dominance and the niche in ecological systems. Science 167:131-139

McNeely JA, Miller KR (1983) IUCN, national parks, and protected areas: priorities for action. Environ Conserv 10:13-21

Mills MGL, Lubchenco J, Robertson IV W, et al (2003) Reflections on the Kruger experience and reaching forward. In: du Toit JT, Rogers $\mathrm{KH}$, Biggs $\mathrm{HC}$ (eds) The Kruger experience: ecology and management of savanna heterogeneity. Island Press, Washington DC, pp 488-501

Mose VN, Nguyen-Huu T, Auger P, Western D (2012) Modelling herbivore population dynamics in the Amboseli National Park, Kenya: application of spatial aggregation of variables to derive a master model. Ecol Complex 10 $42-51$

Moss C (2012) Elephant memories: thirteen years in the life of an elephant family. The University of Chicago Press, Chicago

Moss CJ, Croze H, Lee PC (2011) The Amboseli elephants: a long-term perspective on a long-lived mammal. The University of Chicago Press, Chicago

Muchiru AN, Western DJ, Reid RS (2008) The role of abandoned pastoral settlements in the dynamics of African large herbivore communities. J Arid Environ 72:940-952

Nentwig W (2007) Human environmental impact in the Paleolithic and Neolithic In: Handbook of Paleoanthropology. Springer, Berlin, pp 1881-1900

Niklas KJ, Enquist BJ (2001) Invariant scaling relationships for interspecific plant biomass production rates and body size. Proc Natl Acad Sci 98:2922-2927

Ntiati P (2002) Group ranches subdivision study in Loitokitok division of Kajiado District, Kenya 
Ogutu JO, Piepho H-P, Said MY et al (2016) Extreme wildlife declines and concurrent increase in livestock numbers in Kenya: what are the causes? PLoS One 11:e0163249

Okello MM, Kenana L, Maliti H et al (2016) Population density of elephants and other key large herbivores in the Amboseli ecosystem of Kenya in relation to droughts. J Arid Environ 135:64-74

Palmer AR, Bennett JE (2013) Degradation of communal rangelands in South Africa: towards an improved understanding to inform policy. African J Range Forage Sci 30:57-63

Parker I, Amin M (1983) Ivory crisis. Chatto \& Windus, London

Peet RK (1974) The measurement of species diversity. Ann Rev Ecol Syst 5:285307

Poore M. ED (1962) The method of successive approximation in descriptive ecology. In: Advances in ecological research. Elsevier, pp 35-68

Power ME (1992) Top-down and bottom-up forces in food webs: do plants have primacy. Ecology 73:733-746

Pratt DJ, Greenway PJ, Gwynne MD (1966) A classification of East African rangeland, with an appendix on terminology. J Appl Ecol 3:369-382

R Core Team (2020) R: a language and environment for statistical computing

Redman CL (1999) Human impact on ancient environments. University of Arizona Press

Sarkar S (2006) Long- and short-term dynamics of the Wetlands in the Amboseli Savanna Ecosystem. University of Waterloo, Kenya

Simpson EH (1949) Measurement of diversity. Nature 163:688

Sinclair ARE (1973) Population increases of buffalo and wildebeest in the Serengeti. Afr J Ecol 11:93-107

Sinclair ARE (1979) The eruption of the ruminants. In: Norton-Griffiths M (ed) Serengeti: dynamics of an ecosystem, pp 82-103

Sinclair ARE (1998) Natural regulation of ecosystems in protected areas as ecological baselines. Wildl Soc Bull 26:399-409

Sinclair ARE, Dobson A (2015) Conservation in a human-dominated world. In: Serengeti IV: sustaining biodiversity in a coupled human-natural system. The University of Chicago Press, Chicago, pp 1-10

Sinclair ARE, Metzger KL, Mduma SAR, Fryxell JM (2015) Serengeti IV: sustaining biodiversity in a coupled human-natural system. The University of Chicago Press, Chicago

Smith FA, Gittleman JL, Brown JH (2014) Foundations of macroecology: classic papers with commentaries. The University of Chicago Press, Chicago

Sorensen TA (1948) A method of establishing groups of equal amplitude in plant sociology based on similarity of species content and its application to analyses of the vegetation on Danish commons. Biol Skar 5:1-34

Soule ME, Wilcox BA, Holtby C (1979) Benign neglect: a model of faunal collapse in the game reserves of East Africa. Biol Conserv 15:259-272

Toft NL, McNaughton SJ, Georgiadis NJ (1987) Effects of water stress and simulated grazing on leaf elongation and water relations of an East African grass, Eustachys paspaloides. Funct Plant Biol 14:211-226

Tucker MA, Böhning-Gaese K, Fagan WF et al (2018) Moving in the Anthropocene: global reductions in terrestrial mammalian movements. Science 359:466-469

Veldhuis MP, Ritchie ME, Ogutu JO et al (2019) Cross-boundary human impacts compromise the Serengeti-Mara ecosystem. Science 363:1424-1428

Walker BH, Noy-Meir I (1982) Aspects of the stability and resilience of savanna ecosystems. In: Huntley BJ, Walker BH (eds) Ecology of Tropical Savannas. Springer, New York, pp 556-590

West GB, Brown JH, Enquist BJ (1999) The fourth dimension of life: fractal geometry and allometric scaling of organisms. Science 284:1677-1679

Western D (1973) The structure, dynamics and changes of the Amboseli Ecosystem. University of Nairobi

Western D (2007) A half a century of habitat change in Amboseli National Park, Kenya. Afr J Ecol 45:302-310

Western D, Behrensmeyer AK (2009) Bone assemblages track animal community structure over 40 years in an African savanna ecosystem. Science 324:1061-1064

Western D, Dunne T (1979) Environmental aspects of settlement site decisions among pastoral Maasai. Hum Ecol 7:75-98

Western D, Gichohi H (1993) Segregation effects and the impoverishment of savanna parks: the case for ecosystem viability analysis. Afr J Ecol 31:269-281

Western D, Groom R, Worden J (2009) The impact of subdivision and sedentarization of pastoral lands on wildlife in an African savanna ecosystem. Biol Conserv 142:2538-2546

Western D, Lindsay WK (1984) Seasonal herd dynamics of a savanna elephant population. Afr J Ecol 22:229-244
Western D, Maitumo D (2004) Woodland loss and restoration in a savanna park: a 20-year experiment. Afr J Ecol 42:111-121

Western D, Mose VN, Worden J, Maitumo D (2015) Predicting extreme droughts in savannah Africa: a comparison of proxy and direct measures in detecting biomass fluctuations, trends and their causes. PLoS One 10:e0136516

Western D, Nightingale DL (2004) Environmental change and the vulnerability of pastoralists to drought: a case study of the Maasai in Amboseli, Kenya. Africa Environment Outlook Case Studies: Human Vulnerability to Environment Change. Cambridge University Press, New York

Western D, Tyrrell P, Brehony P et al (2020) Conservation from the inside-out: winning space and a place for wildlife in working landscapes. People Nat 2: 279-291

Western D, Van Praet C (1973) Cyclical changes in the habitat and climate of an East African ecosystem. Nature 241:104-106

Woodroffe R, Ginsberg JR (1998) Edge effects and the extinction of populations inside protected areas. Science 280:2126-2128

Worden J, Reid RS, Gichohi H (2003) Land-use impacts on large wildlife and livestock in the swamps of the greater Amboseli ecosystem, Kajiado district, Kenya. LUCID Project, International Livestock Research Institute

Wright DK (2017) Humans as agents in the termination of the African Humid Period. Front Earth Sci 5:4

\section{Publisher's Note}

Springer Nature remains neutral with regard to jurisdictional claims in published maps and institutional affiliations.

\section{Submit your manuscript to a SpringerOpen ${ }^{\circ}$ journal and benefit from:}

- Convenient online submission

- Rigorous peer review

- Open access: articles freely available online

High visibility within the field

- Retaining the copyright to your article

Submit your next manuscript at $>$ springeropen.com 